\title{
JPCS
}

Peqguruang: Conference Series

Vol. 3 No. 2 Nov. 2021

elSSN: 2686-3472

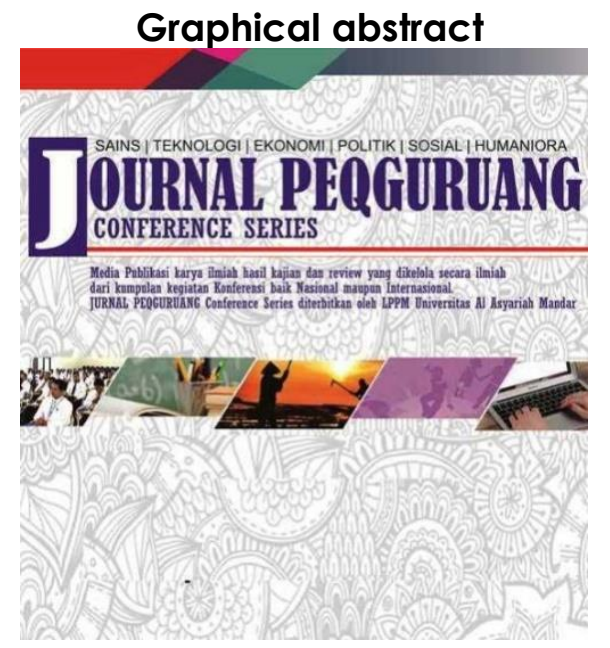

\section{PENGARUH KINERJA APARAT PEMERINTAH DESA TERHADAP KEPUASAN MASYARAKAT ATAS PELAYANAN ADMINISTRASI KEPENDUDUKAN DI DESA SEGERANG KECAMATAN MAPILLI KABUPATEN POLEWALI MANDAR}

${ }^{1 *}$ Husnul Khatimah, 2 Syamsu Alam, ${ }^{3}$ Ade Rahayu

Program Studi PPKn Fakultas keguruan dan ilmu Pendidikan Universitas Al Asyariah Mandar

Corresponding author *husnulinul999@gmail.com

\begin{abstract}
Village government is a manifestation of regional government based on regional autonomy. One of the main objectives of the implementation of regional autonomy is to improve public services. Public services here are services provided by government officials related to the emergence of community satisfaction. But there are some obstacles that occur in the Segerang village office when managing population administration, such as the lack of discipline of government officials coming to the village office, the governmental system that is familial where the apparatus serving as village government officials currently do not see the sub skills of the village government apparatus itself, but see the familiarity system and others. The purpose of this study was to determine the effect of the performance of village government officials on community satisfaction with population administration services in the village of Segerang. The method of collecting data from this study was using a questionnaire, interview, and documentation. This research is descriptive quantitative research. The research sample of 70 people. Based on the results of the study showed that the influence of the performance of village government officials influence community satisfaction with population administration services in the village of Segerang. The results of research data are based on research questionnaires. This is evidenced by 0.92 and the level of contribution between the performance of village government officials towards community satisfaction is $84.64 \%$. While the $t$ test shows that the value of $\mathrm{t}$ arithmetic 19,342<t table 2,649.

Keywords: Apparatus Performance, Community Satisfaction,
\end{abstract}

Abstrak Administrative Services

Pemerintah desa adalah manifestasi dari pemerintah daerah yang berbasis pada otonomi daerah. Salah satu tujuan utama penyelenggaraan otonomi daerah adalah untuk meningkatkan pelayanan public. Pelayanan public disini yaitu pelayanan yang diberikan oleh aparat pemerintah terkait dengan timbulnya kepuasan masyarakat. Tetapi ada beberapa kendala yang terjadi di kantor desa segerang pada saat melakukan pengurusan administrasi kependudukan, seperti kurang disiplinnya aparat pemerintah datang ke kantor desa, system pemerintahannya yang kekeluargaan dimana aparat yang menjabat sebagai aparat pemerintah desa saat ini tidak melihat sub skill dari aparat pemerintah desa itu sendiri, tetapi melihat system keakraban dan lain-lainnya. Tujuan dari penelitian ini adalah untuk mengetahui pengaruh kinerja aparat pemerintah desa terhadapa kepuasan masyarakat atas pelayanan administrasi kependudukan di desa segerang. Metode pengambilan data dari penelitian ini adalah menggunakan angket, wawancara, dan dokumentasi. Penelitian ini adalah penelitian kuantitatif Deskriptif. Sampel penelitian berjumlah 70 orang. Berdasarkan hasil penelitian menunjukkan bahwa pengaruh kinerja aparat pemerintah desa berpengaruh terhadap kepuasan masyarakat atas pelayanan administrasi kependudukan di desa segerang.hasil data penelitian berdasarkan angket penelitian. Hal ini dibuktikan 0,92 dan tingkat kontribusi antara kinerja aparat pemerintah desa terhadap kepuasan masyarakat sebesar 84,64\%. Sedangkan uji t menunjukkan bahwa nilai t hitung $19,342<\mathrm{t}$ tabel 2,649.

Kata Kunci: Kinerja Aparat. Kepuasan Masyarakat, Pelayanan Administrasi

Article history

DOI: https://dx.doi.org/10.35329/jp.v3i2.1523

Received : 20 Juli 2021 | Received in revised form : 19 Agustus 2021 | Accepted : 10 Oktober 2021 


\section{PENDAHULUAN}

Salah satu dampak positif dari otonomi daerah adalah terjadinya perubahan system pemerintahan dari system sentralistik ke system desentralisasi. Desentralisasi dalam otonomi daerah berarti ada pelimpahan wewenang dari pemerintah pusat ke pemrintah daerah. Pelimpahan wewenang tersebut berarti pemberian kewenangan dan keleluasaan kepada daerah untuk mengelola dan memanfaatkan sumber daya daerah secara optimal. (Tikollah: 2018)

Undang-Undang Nomor 22 Tahun 2004 Tentang Pemerintahan Daerah yang juga mengatur Pemerintahan Desa, lebih mengutamakan pelaksanaan otonomi daerah, dimana daerah termasuk juga desa memiliki keleluasaan untuk membentuk dan melaksanakan kebijakan menurut prakarsa dan aspirasi masyarakat. Undang-Undang ini merupakan masa transisi dan memberikan dasar menuju development community yaitu bahwa desa tidak lagi merupakan level administrasi, tidak lagi menjadi bawahan daerah tetapi menjadi Independent community. Sehingga setiap warga desa berhak berbicara atas kepentingan sendiri dan bukan dari atas kebawah seperti yang selama ini terjadi (Maslachah: 2019)

Pemerintah desa adalah bagian dari birokrasi negara dan sekaligus sebagai pemimpin lokal yang memiliki posisi dan peran yang signifikan dalam membangun dan mengelola pemerintahan desa. Pemerintah desa mengemban tugas utama dalam hal menciptakan kehidupan yang demokratis, mendorong pemberdayaan masyarakat serta memberikan pelayanan publik yang baik. (suarno: 2012)

Penyelenggaraan pelayanan masyarakat merupakan upaya negara untuk memenuhi kebutuhan dasar dari hak-hak setiap warga negara atas barang, jasa, dan pelayanan administrasi yang disediakan oleh penyelenggara pelayanan publik. Terkait dengan pelayanan masyarakat dimaksud, Undang-Undang Dasar 1945 mengamanatkan kepada negara untuk memenuhi kebutuhan dasar setiap warga negara demi kesejahteraannya, sehingga efektivitas penyelenggaraan suatu pemerintahan sangat ditentukan oleh baik buruknya penyelenggaraan pelayanan masyarakat. (novianto: 2014)

Kinerja aparat desa harus sesuai dengan pedoman yaitu konstitusi atau undang-undang yang telah dibuat untuk mengelola dan menangani urusa desa. Berdasarkan undang-undang No. 25 Tahun 2009 tentang pelayanan publik menyatakan bahwa pelayanan public adalah kegiatan atau rangkaian kegiatan dalam rangka pemenuhan kebutuhan pelayanan sesuai dengan peraturan perundangundangan bagi setiap negara dan penduduk atas barang, jasa, dan/atau pelayanan administrative yang disediakan oleh penyelenggara pelayanan public terutama di desa, seperti administrasi kependudukan yang meliputi: pengambilan surat keterangann kartu keluarga $(\mathrm{KK})$, surat keterangan tinggal sementara (SKTS) dan ada pelayana yang direkomendasikan antara lain: pengambilan surat keterangan akte kelahiran, akte pernikana, akte tanah, ijin usaha (HO), dan pengantar pemnuatan SKCK dan surat keterangan lainnya (pertiwi: 2018)

Pelayanan akan terlaksnan dengan baik apabila aparatur pemerintah desa dapat memainkan perannya secara langsung dan melibatkan diri dalam memberikan pelayanan kepada masyarakat sesuai dengan tugas dan fungsinya, agar masyarakat puas dengan pelayanan yang diberikan oleh aparat pemerintah desa dan pelayanan yang diharapkan dapat berjalan secara optimal.

Pada pelayanan publik di Desa Segerang masih ditemukan kendala dalam memberikan pelayanan kepada masyarakat terutama pada standar pelayanan yaitu fasilitas pelayanannya belum memadai (tempat duduk, dan fasilitas lainnya), kedisiplinan pegawainnya, dan lainnya.

Adapun sering ditemui pelayanan administrasi di berbagai tempat penuh dengan berbagai masalah seperti mengenai ketepatan waktu, biaya, cara pelayanan, pungutan liar, dan lain sebagainya yang jauh dari bentuk organisasi pelayanan publik yang ideal. Hal tersebut yang harusnya menjadi fokus pemerintah dalam peningkatan kualitas Aparatur Negara untuk pelayanan yang optimal kepada masyarakat (suryani: 2016)

Pada pelayanan aparat pemerintah desa Segerang ada beberapa kendala atau masalah yang terjadi saat masyarakat melakukan pengurusan di kantor desa Segerang yaitu: terkadang masyarakat harus menunggu atau melukakuan pengurusan di lain hari, karena aparat pemerintahnya yang tidak displin (Kantor desa Segerang buka pada jam 9.00 WITA dan tutup jam 12.00 WITA). Tidak adanya kejelasan kapan masyarakat harus dilayani, karena aparatnya tidak tahu menahu dalam melakukan atau membuatkan surat yang masyarakat minta kerena di kantor desa segerang hanya satu yang tahu tentang pengurusan data-data yang ada di desa (operator). Dan tidak adanya keadilan yang merata atau diskriminasi kepada masyarakatnya. Hal tersebut di atas beberapa kali terjadi di kantor Desa Segerang.

Oleh karena itu, penulis menelaah berdasarkan masalah-masalah yang terjadi, khususnya dalam bidang pelayanan administrasi kependudukan di desa Segerang.

Oleh sebab itu, seharusnya terjadi perubahan dalam pelayanan publik kepada masyarakat yang baik dan efektif yang sesuai S.O.P. atau Standar Operasional Prosedur pelayanan. Pelayanan publik bisa dikatakan baik dan efektif jika pelayanan itu memenuhi standar pelayanan publik yaitu kesederhanaan, kejelasan dan kepastian, 
kemampuan, keterbukaan, efesien, ekonomis, keadilan merata dan ketetapan waktu. Dengan menjalankan fungsi dan tugasnya dan memiliki wewenang yang istimewah dantidak menyalahgunakan wewenang, jabatan atau kekuasaan dapat memberikan pelayanan yang berkualitas sebagai pelayan masyarakat.

Berdasarkan kendala-kendala di atas menggambarkan bahwa pelayanan yang diberikan penyelenggara pelayanan publik atau aparat pemerintah di desa Segerang belum dapat memberikan kepuasan kepada masyarakat. Karena itulah, penulis ingin meneliti di desa terutama Desa Segerang, dengan judul Pengeruh Kinerja Aparat Pemerintah Desa terhadap

Kepuasan Masyarakat Atas Pelayanan Administrasi Kependudukan di Desa Segerang Kecamatan Mapilli Kabupaten Polewali Mandar.

\section{METODE PENELITIAN}

\section{Jenis penelitian}

Jenis penelitian tersebut kualitatif deskriptif. Kualitatif Dan dideskripsikan secara deduksi yang berangkat dari teori-teori umum, lalu dengan observasi untuk menguji validitas keberlakuan teori tersebut ditariklah kesimpulan. Kemudian dijabarkan secara deskriptif, karena hasilnya akan diarahkan untuk menggambarkan atau mendeskripsikan data yang diperoleh dan untuk menjawab rumusan masalah dari penelitian tersebut.

\section{Tempat dan Tempat Penelitian}

Penelitian dilakukankan di desa Segerang Kecamatan Mapilli Kabupaten Polewali Mandar,

Dan Penelitian ini dilakukan sejak penelitian pada 30 Desember 2019 sampai pada saat ujian skripsi di laksanakan tepat pada tanggal 7 Juli 2020

\section{Populasi dan Sampel Penelitian}

1. Populasi Penelitian

Populasi adalah keseluruhan jumlah yang terdiri atas objek atau subjek yang mempunyai karakteristik dan kualitas tertentu, sebanyak 411 KK (kartu Keluarga) dan Populasi 1.535 Penduduk di Desa Segerang.

2. Sampel Penelitian

Jumlah sampel yang di peneliti tetapkan sebanyak 70 oarang yang peranah melakukan proses pelayanan di kantor desa segerang, termasuk masyarakat dan apparat pemerintah desa segerang

\section{Defenisi Operasional Variabel}

1. Kinerja Aparat Pemerintah

Hasil kerja yang dicapai seseoarng karyawan sesuai dengan wewenang atau tanggung jawab

masing-masing selama priode waktu tertentu.

2. Kepuasan Masyarakat

Kepuasan masyarakat sebagai perasaan senang atau kecewa seseorang yang dilayani setelah membandingkan antara persepsi kinerja atau hasil suatu produk dengan harapan-harapannya..

\section{Instrumen Penelitian}

Instrumen penelitian adalah alat atau fasilitas yang digunakan peneliti dalam mengumpulkan data agar pekerjaannya lebih mudah dan hasilnya lebih baik, dalam arti cermat, lengkap dan sistematis sehingga lebih mudah diolah oleh peneliti.

\section{Teknik pengumpulan data}

1 Angket merupakan teknik pengumpulan data yang dilakukan dengan cara memberi seperangkat pertanyaan atau pernyataan tertulis kepada responden untuk di jawab.

2 Wawancara merupakan teknik pengumpulan data yang dilakukan dengan cara memberi seperangkat pertanyaan kepada narasumber secara tatap muka dengan sumber data atau narasumber.

3. metode observasi yaitu penelitian ini mengamati secara langsung dengan mengamati keadaan di lokasi penelitian.

4. Metode dokumentasi yaitu metode pengumpulan data yang diperoleh dari lapangan dan keterangannya secara tertulis, tergambar, terekam atau tercetak.

\section{Teknik Analisis Data}

Teknik analisis data dalam penelitian kuantitatif menggunakan statistik. Terdapat beberapa dua macam statistik yang digunakan untuk analisis data dalam penelitian, yaitu statistik deskriptif, dan statistik inferensial.

1 Analisis statistik deskriptif

Analisis deskriptif adalah analisis yang dilakukan untuk menilai karakteristik dari sebuah data.

Ket:

$$
P=F / n \times 100 \%
$$

$\mathrm{P}=$ Presentase

$\mathrm{F}=$ Frekuensi jawaban responden

$\mathrm{n}=$ jumlah responden

2. Analisis Statistik Infrensial

Digunakan untuk menguji hipotesis penelitian,. Untuk mengetahui tingkat korelasi/hubungan antara variable $\mathrm{x}$ dengan variable $\mathrm{y}$. Analisis infrensial digunakan untuk menguji hipotesis penelitian.

$$
r_{X Y}=\frac{N \sum X Y-\left(\sum X\right)\left(\sum Y\right)}{\sqrt{\left.\left\{N . \Sigma X^{2}-\left(\sum X\right)^{2}\right\} N N Y^{2}\left(\sum Y\right)^{2}\right\}}}
$$

\footnotetext{
Ket :

r_uy $\quad=$ Koefisien korelasi antara variabel $\mathrm{x}$

dan $y$.

Xy =Jumlah hasil perkalian antara

variabel
} 
$\mathrm{x}$ dengan variabel $\mathrm{y}$

$x \quad=$ jumlah nilai setiap item

$\mathrm{y} \quad=$ jumlah nilai konstan

$\mathrm{n} \quad=$ jumlah subjek penelitian

Untuk mengetahui apakah terdapat hubungan yang signifikan antara pengaruh kinerja aparat pemerintah desa terhadap kepuasan masyarakat maka dilakukan pengujian signifikasi dengan uji -t dengan rumus sebagai berikut:

$$
t=\frac{r \sqrt{N-2}}{\sqrt{1-r^{2}}}
$$

Adapun kaidah pengujian dinyatakan sebagai berikut :

- Jika $\mathrm{t}$ hitung $\geq \mathrm{t}$ tabel, maka terdapat hubungan signifikan

- Jika t hitung $\leq \mathrm{t}$ tabel, maka tidak terdapat hubungan signifikan

Sedangkan untuk menyatakan besar kecilnya kontribusi variabel $\mathrm{x}$ terhadap variabel $\mathrm{y}$ dapat ditentukan dengan persamaan koefisien determinasi sebagai berikut

$$
\mathrm{Kd}=\mathrm{R}^{\wedge} 2 \times 100 \%
$$

Ket ::

$\mathrm{Kd}=$ Koefisien determinasi

$\mathrm{R}^{\wedge} 2$ =besarnya koefisien korelasi ganda

\section{HASIL DAN PEMBAHASAN}

Berdasarkan nila angket/kuisioner yang dihimpun dan diolah dari 70 responden, maka untuk mendeskripsikan hasil penelitian berdasarkan variable penelitian yang telah diperoleh akan dikelompokkan dalam table presentase sebagai berikut:

\section{a. Kinerja Aparat Pemerintah Desa}

Tabel 4.1. Sikap Masyarakat Yang Diberikan Pelayanan Oleh Aparat Pemerintah Desa Segerang

\begin{tabular}{cccc}
\hline No. & Jawaban & Frekuensi & Presentase \\
\hline 1. & Sangat Baik & 12 & $100 \%$ \\
\hline 2. & Baik & - & - \\
\hline 3. & Cukup Baik & - & - \\
\hline 4. & Kurang Baik & - & - \\
\hline 5. & Tidak Baik & - & - \\
\hline & Jumlah & 12 & $100 \%$ \\
\hline
\end{tabular}

Sumber : Daftar pertanyaan angket terhadap pengaruh kinerja aparat pemerintah desa terhadap kepuasan masyarakat

Berdasarkan data pada tebel diatas dapat disimpulkan bahwa mayoritas aparat pemerintah desa menilai bagaimana sikap masyarakat terhadap pelayanan yang diberikan oleh aparat pemerintah kepada masyarakat sangat baik. Hal ini terlihat dari jumlah respon aparat pemerintah desa yang menjawab sangat baik sebanyak 100\%.
Tabel 4.2 Pelayanan Yang Dilakukan Oleh Anda Sebagai Aparat Pemerintah Desa Sesuai Jadwal Yang Telah Di Tentukan

\begin{tabular}{rccc}
\hline No. & Jawaban & Frekuensi & Presentase \\
\hline 1. & Sangat Baik & 3 & $25 \%$ \\
\hline 2. & Baik & 9 & $75 \%$ \\
\hline 3. & Cukup Baik & - & - \\
\hline 4. & Kurang Baik & - & - \\
\hline 5. & Tidak Baik & - & - \\
\hline & Jumlah & 12 & $100 \%$ \\
\hline
\end{tabular}

Sumber: Daftar pertanyaan angket terhadap pengaruh kinerja aparat pemerintah desa terhadap kepuasan masyarakat

Berdasarkan data pada table diatas dapat disimpulkan bahwa aparat pemerintah di desa Segerang menilai pelayanan yang dilakukan oleh aparat pemerintah desa sesuai jadwal yang telah di tentukan di kantor desa Segerang yang baik. Hal ini terlihat dari jumlah responden yang menjawab Sangat Baik yaitu sebesar $25 \%$ dan responden yang menjawab Baik sebanyak 75\%.

Tabel 4.3 Kedisiplinan Dalam Melaksanakan Tugasnya

\begin{tabular}{clcl}
\hline No & Jawaban & Frekuensi & Presentase \\
\hline 1. & Sangat baik & 1 & $0,8 \%$ \\
\hline 2. & Baik & 4 & $33 \%$ \\
\hline 3. & Cukup Baik & 7 & $58 \%$ \\
\hline 4. & Kurang Baik & - & - \\
\hline 5. & Tidak Baik & - & - \\
\hline & Jumlah & 12 & $100 \%$ \\
\hline
\end{tabular}

Sumber : Daftar pertanyaan angket terhadap pengaruh kinerja aparat pemerintah desa terhadap kepuasan masyarakat

Berdasarkan data pada table diatas dapat disimpulkan bahwa kedisiplinan aparat pemerintah dalam melaksanakan tugasnya sudah cukup baik. Hal ini terlihat dari jumlah responden yang menjawab sangat setuju $0,8 \%$, responden yang menjawab baik 33\% dan responden yang menjawab cukup baik sebanyak $58 \%$.

b. Kepuasan Masyarakat

Tabel 4.4 Kedispinan Aparat Pemerintah Desa Datang Ke Kantor Desa

No Jawaban Frekuensi Presentase

\begin{tabular}{cccc}
\hline 1. & Sangat Baik & 4 & $6 \%$ \\
\hline 2. & Baik & 8 & $14 \%$ \\
\hline 3. & Cukup Baik & 32 & $55 \%$ \\
\hline 4. & Kurang Baik & 16 & $27 \%$ \\
\hline 5. & Tidak Baik & - & - \\
\hline & Jumlah & 58 & $100 \%$ \\
\hline
\end{tabular}

Sumber : Daftar pertanyaan angket terhadap pengaruh kinerja aparat pemerintah desa terhadap kepuasan 
Berdasarkan data pada tabel diatas dapat disimpulkan bahwa mayoritas jawaban masyarakat megenai kedisiplinan aparat pemerintah datang ke kantor desa sudah baik. Hal tersebut dapat dilihat dari responden yang menjawab sangat baik yaitu hanya $6 \%$, responden yang menjawab baik yaitu $14 \%$, yang menjawab baik sebanyak $55 \%$ dan yang menjawab kurang baik $16 \%$.

Tabel 4.5 Kedisiplinan Dalam Memberikan Pelayanan Kepada Masyarakat

\begin{tabular}{cccc}
\hline No. & Jawaban & Frekuensi & Presentase \\
\hline 1. & Sangat Baik & 2 & $3 \%$ \\
\hline 2. & Baik & 26 & $44 \%$ \\
\hline 3. & Cukup Baik & 25 & $43 \%$ \\
\hline 4. & Kurang Baik & 4 & $6 \%$ \\
\hline 5. & Tidak Baik & - & - \\
\hline & Jumlah & 58 & $100 \%$ \\
\hline
\end{tabular}

Sumber : Daftar pertanyaan angket terhadap pengaruh kinerja aparat pemerintah desa terhadap kepuasan

Berdasarkan data pada tabel diatas dapat disimpulkan bahwa masyarakat yang menjawab tentang kedisiplinan aparat pemerintah desa terhadap kepuasan masyarakat sudah baik. Hal ini dapat dilihat dari responden yang menjawab sangat baik yaitu hanya 3\%, responden yang menjawab baik sebesar 44\%, responden yang menjawab cukup baik sebanyak 43\%, dan responden yang menjawab kurang baik $6 \%$.

Tabel 4.6 . Ketepatan Waktu Dalam Melayani Masyarakat

\begin{tabular}{cccc}
\hline No. & Jawaban & Frekuensi & Presentase \\
\hline 1. & Sangat Baik & 8 & $13 \%$ \\
\hline 2. & Baik & 25 & $43 \%$ \\
\hline 3. & Cukup Baik & 25 & $43 \%$ \\
\hline 4. & Kurang Baik & 5 & $8 \%$ \\
\hline 5. & Tidak Baik & - & - \\
\hline & Jumlah & 58 & $100 \%$ \\
\hline
\end{tabular}

Sumber : Daftar pertanyaan angket terhadap pengaruh kinerja aparat pemerintah desa terhadap kepuasan

Berdasarkan data dari tabel diatas dapat simpulkan bahwa jawaban responden atau masyarakat tentang ketepatan waktu petugas pelayanan dalam melayani masyarakat sudah baik. Hal tersebut terlihat dari jumlah responden yang menjawab baik yaitu sebesar $43 \%$, responden yang menjawab cukup baik juga sebanyak $43 \%$, responden yang menjawab sangat baik sebesar 13\% dan yang menjawab kurang baik sebanyak $8 \%$. c. Uji Hipotesis

1. Perhitungan koefisien korelasi $®$ dan koefisien determinasi (KD)

Perhitungan koefisien korelasi digunakan untuk mengetahui hubungan antara variable (X) terhadap variable $(\mathrm{Y})$. hal ini, perhitungan koefisien korelasi digunakan untuk mengetahui tingkat pengaruh kinerja aparat pemerintah desa terhadap kepuasan masyarakat atas pelayanan administrasi kependudukan di Desa Segerang. Untuk mancari korelasi antara variable (X) terhadap variable (Y). digunakan persamaan korelasi Person ProductMoment sebagai berikut:

$$
\begin{aligned}
& r_{x Y}=\frac{n \cdot \sum X Y-\left(\sum X\right)\left(\sum Y\right)}{\sqrt{\left\{n \cdot \sum X^{2}-\left(\sum X\right)^{2}\right\}\left\{n \cdot \sum Y^{2}\left(\sum Y\right)^{2}\right\}}} \\
& r x y=\frac{70 \cdot(142,476)-(3489)(2861)}{\left.\sqrt{\left\{70 .(175,621)-(3489)^{2}\right.}\right\}\left\{70 .(119,003)(2861)^{2}\right.} \\
& r x y=\frac{(9,973,320)-(9,985,518)}{\sqrt{\{(12,293,470)-(12,173,121)}\}\{8,330,210)\}} \\
& r \mathrm{xy}=\frac{12,198}{\sqrt{\{120,349}\}\{144,889\}} \\
& r x y=\frac{12,198}{\sqrt{17,437,246,261}} \\
& r \mathrm{xy}=\frac{12,198}{132,050.16} \\
& r \mathrm{xy}=0,92
\end{aligned}
$$

Dari hasil perhitungan koefisien korealsi diatas, dapat diketahui bahwa kinerja aparat pemerintah desa segerang berpengaruh terhadap kepuasan masyarakat. merujuk pada buku sugiyono (2016:184), interpretasi koefisien korelasi di bagi kedalam beberapa kriteria sebagai berikut:

\begin{tabular}{cc}
\hline Interval koefisien & Tingkat hubungan \\
\hline $0,00-0,199$ & Sangat Rendah \\
\hline $0,20-0,399$ & Rendah \\
\hline $0,40-0,599$ & Sedang \\
\hline $0,60-0,799$ & Kuat \\
\hline $0,80-1.00$ & Sangat Kuat
\end{tabular}

Sumber : buku metode penelitian kuantitatif,kualitatif, dan R\&D; Sugiyono

Untuk mengetahui besarnya kontribusi variable $\mathrm{Y}$ maka dapat dihitung dengan menggunakan persamaan koefisien determinasi sebagai berikut:

$\mathrm{KP}=r^{2} \times 100 \%$

$\mathrm{Kp}=(0,92)^{2} \times 100 \%$

$\mathrm{Kp}=0,8464 \times 100 \%$

$\mathrm{Kp}=84,64 \%$ 
Koefisien determinasi yang diperoleh sebesar 84,64\%. Hal ini terlihat kontribusi variable X (kinerja aparat pemerintah desa) tidak terlalu berpengaruh terhadap kepuasan masyarakat yang ada di desa segerang. Atau dengan kata lain bahwa pengaruh kinerja aparat pemerintah desa segerang memiliki pengaruh

terhadap kepuasan masyarakat atas pelayanan administrasi kependudukan di desa segerang sebesar $84,64 \%$ dan sisahnya sebesar : $100 \%-84,64 \%=15,36 \%$.

Untuk mengetahui signifikan koefisien korelasi person product moment sebesar 0,92 diatas, digunakan uji t karena termasuk sampel besar ( $\mathrm{n}>30$ dengan rumus:

$$
\begin{aligned}
t & =\frac{r \sqrt{N-2}}{\sqrt{1-r^{2}}} \\
t & =\frac{0,92 \sqrt{70-2}}{\sqrt{1-0,8464}} \\
t & =\frac{0,92 \sqrt{68}}{\sqrt{0,1536}} \\
t & =\frac{0,92 \cdot 8 \cdot 24}{0,3919183588} \\
t & =\frac{7,5808}{0,3919183588} \\
\mathrm{t} & =19.342
\end{aligned}
$$

Berdasarkan perhitungan di atas dengan ketentuan ; $d b=\mathrm{n}-1=70-1=69$ dan a $=0,05$ maka di dapatkan angka $=2,649$. karena t hitung $(19,342)>\mathrm{t}$ tabel (2,649), dengan demikian dapat dikatakan bahwa terdapat hubungan yang signifikan antara kinerja aparat pemerintah desa terhadap kepuasan masyarakat. Maka dapat di simpulkan bahwa kinerja aparat pemerintah desa segerang berpengaruh terhadap kepuasan masyarakat di desa segerang.

\section{SIMPULAN}

Berdasarkan hasil wawancara, beberapa responden menyatakan bahwa aparat pemerintah dalam hal pelayanan, sikap dan perlakuannya sangat baik atau sudah memuaskan tetapi dalam kedisiplinannya kurang, biasanya dikantor desa segerang pelayanannya hanya sampai jam 13.00 atau sehabis dzuhur. Dan jam buka kantor desa itu tidak konsisten biasa jam 08.00, 09.00 dan juga jam 10.00. itu yang menjadi penghambat masyarakat ketika ingin melakukan pelayanan administrasi kependudukan di kantor desa segerang. Ketika aparat tidak standby di kantor desa, itu akan menjadi kendala tersendiri bagi masyarakat yang ingin melakukan pengurusan administrasi kependudukan. Dan dalam system pemerintahan di kantor desa segerang, memakai system pemerintahan yang kekeluargaan dimana aparat yang menjabat sebagai aparat pemerintah desa saat ini tidak melihat sub skill dari aparat pemerintah desa itu sendiri, tetapi melihat system keakraban dan lain-lainnya. Dan dalam hal tanggung jawab aparat pemerintah dalam memberikan pelayanan kepada masyarakatnya itu masih kurang dikarenakan, banyaknya aparat pemerintah desa yang belum tahu tentang bagaimana S.O.P menjadi seorang aparat

pemerintah desa, kerena ia pernah melakukan pengurusan atau pembuatan surat keterangan di kantor desa tetapi sampel atau data surat tersebut tidak ada, banyaknya aparat yang tidak tahu menahu untuk membuat surat, penomoran dan lainlainnya. Inilah yang perlu di tingkatkan oleh aparat pemerintah desa yang ada di desa segerang saat ini.

Hasil penelitian menunjukkan bahwa pengaruh kinerja aparat pemerintah desa berpengaruh terhadap kepuasan masyarakat atas pelayanan administrasi kependudukan di desa segerang.hasil data penelitian berdasarkan angket penelitian. Hal ini dibuktikan 0,92\% dan tingkat kontribusi antara kinerja aparat pemerintah desa terhadap kepuasan masyarakat sebesar 84,64\%. Sedangkan uji t menunjukkan bahwa nilai t hitung $19,342<\mathrm{t}$ tabel 2,649, hal tersebut menunjukkan bahwa pengaruh kinerja aparat pemerintah desa berpengaruh terhadap kepuasan masyarakat.

Jadi dengan demikian hipotesa yang menyatakan "pengaruh kinerja aparat pemerintah desa terhadap kepuasan masyarakat terhadap pelayanan administrasi kepandudukan di desa Segerang" dapat dinyatakan diterima atau teruji.

Dengan hasil perhitungan tersebut dapat disimpulkan bahwa kinerja dan kepuasan masyarakat yaitu kinerja aparat pemerintah desa dalam melayani masyarakat sangat berpengaruh terhadap kepuasan dari masyarakat itu sendiri. Karena pelayanan yang baik masyarakat akan merasa puas sehingga masyarakat percaya dan senang terhadap aparat pemerintah desa.

\section{DAFTAR PUSTAKA}

Maslachah, Dewi Yulia. 2019. Respon masyarakat desa terhadapa pelayanan administrasi pemerintah desa. Vol, 13. No, 2. 2019.

Pertiwi, Umi. 2018. Factor yang mempengaruhi kinerja aparatue pemerintah desa dalam akuntabilitas dana desa. Vol 6, No. 3 desember 2018. https://ejournal.upi.edu/index.php/jrak

Sugiyono. 2016. Metode penelitian kuantitatif, kualitatif,dan $R \& D$. 
Suryani, Irma. 2016. Pelayanan administrasi kependudukan pada kantor kecamatan Pattallangssang Kabupaten Gowa. Vol. 2, No. 2.

Suwarno, Joni. 2012. Kualitas Pelayanan Pemerintahan Desa (Studi Pelayanan KTP Dan Kk Di Desa Teluk Kepayang Kecamatan Kusan Hulu Kabupaten Tanah Bumbu).https://www.neliti.com/publications/1014 18/kualitas-pelayanan-pemerintahan-desa-studipelayanan-ktp-dan-kk-di-desa-teluk-ke

Tikollah, Ridwan. M. 2018. Analisis pengelolaan alokasi dana desa (ADD) di kecamatan mare kabupaten Bone. Vol.1, No. 1, Januari 2018. https://ojs.umn.ac.id/Jekped

Noviyanto, Fiftin. 2014. implementasi Sikades (Sistem Informasi Kependudukan Desa) Untuk Kemudahan Layanan Administrasi Desa Berbasis Web Mobile. Journals. Universitas

Ahmad Dahlan Jogjakarta ( Vol. 8, No. 1 januari 2014.

https://www.neliti.com/publications/101999/implementasisikdes-sitem-informasi-kependudukan-desauntuk-kemudahan-layanan) 